\title{
Research on Integrating Ideological and Political Education into College English Teaching
}

\author{
Xue $\mathrm{Li}^{*}$ \\ School of Foreign Languages, Dalian Jiaotong University, Dalian, Liaoning 116028, China \\ *Corresponding author. Email: lixue_sherry@djtu.edu.cn
}

\begin{abstract}
With the continuous strengthening of ideological and political education in colleges and universities, besides ideological and political courses in universities, other courses also take the important responsibility and mission of ideological and political education for students. College English is a compulsory basic course, which plays an important role in "ideological and political education". This paper first expounds the concept of "integrating ideological and political education into courses", then analyzes the necessity, feasibility and current situation of integrating ideological and political education into college English course, and finally explores the effective implementation ways of integrating ideological and political education into college English course. Based on the theory of integrating ideological and political education into courses, as college English teachers, we should make a great effort to improve the quality of college English teaching and promote the overall development of college students' comprehensive quality and ideological quality education. Keywords: ideological and political education, college English teaching, implementation
\end{abstract}

\section{INTRODUCTION}

In December 2016, Chairman Xi Jinping emphasized in the national college ideological and political work conference that we should make good use of classroom teaching as the main channel. Ideological and political education should be strengthened in the process of improvement, promoting the affinity and pertinence of ideological and political education to make all kinds of courses and ideological and political theory courses in the same direction and form a synergistic effect.[1] In December 2017, the Ministry of Education first used the term "integrating ideological and political education into courses" in the implementation outline of improving the quality of ideological and political work in colleges and universities. New era has put forward new requirements for universities and posed new challenges to the ideological and political education in the new situation. Ideological and political work should be undertaken throughout the whole process of education and teaching. In terms of college English course, we should permeate the concept of integrating ideological and political education into college English and carry out the practical application in the process of teaching, so as to improve the ideological depth of college English teaching, the innovation of college English teaching method, making a contribution to the development of education course.

\section{THE CONCEPT OF INTEGRATING IDEOLOGICAL AND POLITICAL EDUCATION INTO COURSES}

The so-called integrating ideological and political education into courses theory refers to a kind of comprehensive education concept that all kinds of courses and ideological and political theory courses go hand in hand to form a synergistic effect, taking "strengthening morality and cultivating people" as the fundamental task of education, and realize the education pattern of all the students and all the courses. Its basic meaning is that all college courses have the dual functions of imparts knowledge to cultivate ability and ideological and political education, bearing the role of cultivating university students' world view, outlook on life and values. [2]

For a long time, the ideological and political education of college students in China is mainly conducted by ideological and political counselors and five traditional ideological and political courses, but it is far from enough to only rely on these two courses. The idea of integrating ideological and political education into courses means that ideological and political education can go beyond the ideological and political theory class to the general education class and the professional class, so as to expand the space of ideological and political work in colleges and universities, and subtly convey socialist ideals, beliefs and correct values to students. 


\section{THE NECESSITY OF INTEGRATING IDEOLOGICAL AND POLITICAL EDUCATION INTO COLLEGE ENGLISH COURSE}

Virtue is the root of life, which should provide students with a "clean environment" in the teaching process, and set role models, so that students can become the backbone of the country after graduation. Virtue and knowledge have always been what people need to have and pursue. Colleges and universities are places for educating people. The success or failure of education depends on whether the trained talents can support the party's line and principles, serve the country and serve the society. Therefore, colleges and universities must put moral education in an important position in the process of running schools, just as the so-called education-oriented, moral education first, especially when China's higher education is gradually getting popularization now. At present, many college students have the phenomenon that their thoughts are incompatible with the traditional culture and their concepts are contrary to each other. There is no doubt that these problems show one aspect on the surface, while in the final analysis, they are the problems of education. University is an important unit for the growth of young people. To solve these seemingly common social problems, it is necessary to integrate ideological and political education into courses and finally form a good and positive school atmosphere. Language is a part of culture and an important medium to convey culture. Language and culture coexist and depend on each other. As a language, English is not only a course, but also a cultural and moral bridge between English and the target language. We should attach great importance to the ideological and political work of young generation and improve the ideological and political work system, innovating ideological and political work content and form, to guide the youth to form the correct outlook on world, life, and values. We should enhance confidence in the path, theory, system and culture of socialism with Chinese characteristics, and ensure that the younger generation becomes builders and successors of socialism [3]. Therefore, college English education is not only a basic knowledge of the pure language teaching; more importantly, it will make students learn to distinguish right from wrong, good from evil, and form effective social governance and good social order through the influence of Chinese and foreign excellent traditional culture. Through the moral education of, it can stimulate students' patriotism, enhance their national pride and help them form a positive life value system.

\section{THE FEASIBILITY OF INTEGRATING IDEOLOGICAL AND POLITICAL EDUCATION INTO COLLEGE ENGLISH COURSE}

In colleges or universities, English courses have a long duration and a large proportion of class hours. NonEnglish major students usually take English classes twice a week, which makes English classes enjoy a unique advantage in class time. College English teaching materials contain rich ideological and political materials and moral resources, so ideological and political education can be carried out naturally in the process of English teaching. In addition, the psychology of "seeking novelty" makes students interested in the outside world and novel cultures. In the collision between European and American customs and traditional Chinese values, a little guidance is needed to enable students to critically view western and Chinese cultures and values. In this way, college English classes conform to the requirements of the Times. It is easy to incorporate ideological and political work into college English education by extracting cultural essence and value paradigms in English classes, integrating spiritual guidance of ideals and beliefs into the language learning.

\section{THE CURRENT SITUATION OF INTEGRATING IDEOLOGICAL AND POLITICAL EDUCATION INTO COLLEGE ENGLISH COURSE}

\subsection{Some Universities do not Pay Attention to Quality Education}

From the perspective of the school, the traditional college English talent training program focuses on the improvement of basic English knowledge and skills such as listening, speaking, reading, writing and translation. The educators in many schools are limited to the understanding of subject knowledge and neglect the important role of cultivating students' own quality and ability and moral education [4]. There is a direct relationship between the assessment of students' test scores and teachers' teaching. Teachers generally guide students' interest in learning and encourage students to study hard by taking the CET-4 and CET-6 exams and personal future career development. They seldom encourage students from core values such as patriotism, self-confidence and serving the society. Therefore, it is unreasonable and unscientific standard to evaluate teachers' teaching quality by measuring students' examination level with scores. Students cannot get their graduation certificate in order to pass the exam. This method of English learning is not advocated in qualityoriented education. 


\subsection{Teachers Lack Their Own Ideological and Moral Cultivation}

Due to the particularity of college English courses, many English teachers have overseas education background. Because of studying abroad, some English teachers are more familiar with the conditions and customs of foreign countries, so their understanding of the domestic society is limited. In the process of teaching, some college English teachers only focus on imparting professional knowledge, professional teaching and professional development, regardless of students' ideological and political work, lack of integration of ideological and political ideas, and pay no attention to the ideological state of college students. Some college English teachers think that ideological and political education is the matter of ideological and political teachers and counsellors, which is not the duty of them.

College English teachers are lack of systematic theoretical guidance and study on ideological and political education, lack of understanding on the meaning and connotation of integrating ideological and political education into courses, and fail to integrate ideological education into teaching. In the process of teaching, even if the content of some ideological and political education can be consciously added, it is often just a little bit to the point, not deep enough.

\subsection{The Proportion of Ideological and Political Contents in College English Textbooks Is Small}

In English teaching, the content of teaching materials is an important part of learning English, and it is one of the media that reflects the basic ideas and methods of English teaching. Students learning about ideological and political ideas mainly depend on teachers and textbooks which contain the elements of ideological and political knowledge. In English textbooks, some can well integrate the functions and elements of ideological and political education. On the contrary, the content of some textbooks is dull, the knowledge points are empty, and there is no key point, only pay attention to the application of gorgeous language, especially the western literature knowledge, lack of inheritance and accumulation of traditional Chinese culture. [5]

The compilation of these textbooks makes Chinese culture ignored and weakened in the content selection. Western culture occupies a large proportion, and college students are too much influenced by western festivals, culture and ideology, which is not conducive to the establishment and cultivation of socialist core values. This phenomenon leads to students' blind worship of western culture, and their recognition of traditional Chinese culture is constantly weakened, which affects the foothold of excellent traditional Chinese culture and its foreign exchange and export.

\section{THE IMPLEMENTATION OF INTEGRATING IDEOLOGICAL AND POLITICAL EDUCATION INTO COLLEGE ENGLISH COURSE}

\subsection{Improve the Ideological Consciousness of College English Teachers}

Firstly, college English teachers should fully realize the importance of ideological and political education throughout the whole process of college education, improve their ideological understanding and ideological and political education ability by constantly updating their theoretical knowledge and caring about the development of the country, and integrate ideological and political education elements into their college English teaching consciously and systematically. As the guider of classroom teaching, teachers should persistently cultivate and carry forward the socialist core values, and cultivate students' feelings of homeland, international vision, thinking quality and humanistic quality. Secondly, colleges and universities should train and guide college English teachers in the aspect of curriculum ideological and political, and invite experts and scholars or teachers with rich teaching experience to give academic reports or teaching model classes, so that teachers can deeply understand the concept and connotation of curriculum ideological and political, so that they can conduct ideological and political education for students in the teaching process. Thirdly, in addition to "teaching", the university teachers own moral character, personality charm is the best "example". During the communication between teachers and students in class and out of class, they should be able to let students feel the core socialist values such as being a teacher, being patriotic, abiding by the law, loving their jobs, being honest and trustworthy, and become the best learning model for students.

\subsection{Adapt Current College English Textbooks and Compile School-based Textbooks}

College English teaching materials should fully embodies the Chinese elements, introduce Chinese native culture, integrating Chinese characteristics into the content of the chapter, for example, Chinese traditional culture, festival, hero, hot words such as "Chinese dream", "national rejuvenation", "One Belt, One Road", "four confidence" in the current China's social development. In addition to introducing and comparing Chinese and foreign cultures, the school-based teaching materials of colleges and universities should reflect local characteristics and incorporate the cultural phenomena that affect the local culture into the teaching materials [6]. Choose English materials that promote positive energy. In order to realize the educational function of English teaching, we should expand the content modules of ideological and political 
education, such as patriotism education, ideological quality education, behaviour and habit education, and Chinese culture education. Such ideological and political education in English courses can not only improve students' language application ability, but also cultivate their thinking quality. More importantly, it helps students to strengthen their cultural confidence, arouse their national pride and develop the ability to spread Chinese culture, tell Chinese stories and represent Chinese voices in English.

\subsection{Reconstruct the Teaching Model}

Based on the analysis of academic situation, a blended college English ideological and political teaching model "classroom plus network" is constructed, aiming at exerting the collaborative role of "classroom ideological and political plus network ideological and political" in educating students [7]. We should firmly grasp the main position of educating students in class, and create a learning atmosphere in which students actively prepare before class, fully interact with each other in class and summarize carefully after class. While effectively inputting ideological and political education elements into college English courses, it also guides students to internalize them and output them orally or in writing, so as to improve their thinking quality, cultural accomplishment and language ability.

Nowadays, the network is developed and various media resources are abundant. Teachers should select videos, audio and articles with positive energy as students' English learning materials, not only to improve students' English application ability, but also to help students form a correct outlook on life, values, world view, and guide students to learn through the west and the past. Students summarize their problems after learning materials independently after class, output their learning gains in English by group discussion in class, and the teacher finally summarizes and expands. Such flipped classroom teaching method not only helps students accumulate language materials, but also relives the extensive and profound Chinese culture, which is conducive to enhancing students' cultural confidence and sense of national honor.

\subsection{Implement Diversified and Comprehensive Evaluation}

The evaluation of college English teaching should carry out a diversified and all-round examination and evaluation for students. Since the teaching of ideological and political courses in college English involves ideological and ideological aspects, teachers can adopt a variety of flexible evaluation methods, such as video assignment, PPT homework, case study or classroom learning reflection report and study report task. Establish the ideological and political study portfolio for each student and allow students to conduct self-evaluation and mutual evaluation after group discussion and report, which will stimulate students' learning motivation, help teachers master students' learning dynamics and adjust teaching timely

\section{CONCLUSION}

Strengthening the ideological and political education for college students is an important task in the construction of a socialist country, which has a far-reaching impact on the development of society. Therefore, the ideological and political education should be integrated into the college English class. The quality of ideological and political education of college students should be improved through the combination of teaching materials and practical theoretical basis by making use of its many advantages in the course. In the process of college English teaching, we should realize the importance of cultivating college students' humanistic qualities and national feelings, and infiltrate moral education into English teaching to enable students to absorb knowledge and receive moral education subtly, so as to achieve the best combination of subject teaching and moral education. College English teaching should be organically combined with the theory of integrating ideological and political into course. We should make efforts to explore the distinctive characteristics of integrating ideological and political into college English teaching, improve the system and mechanism of educating students in an all-round way and fully explore the connotation of moral education in college English courses. Only by keeping pace with The Times can we carry forward the excellent cultural heritage of the Chinese nation and effectively integrate it with the core socialist values, can we better face the future, realize the Chinese dream and realize the great rejuvenation of the Chinese nation.

\section{REFERENCES}

[1] Xi jinping, The Important Speech at the National Education Conference. http//www.xinhuanet.com//2018 -09/10/c_1123406247.htm.

[2] An Xiumei, Research on College English and Integrating Ideological and political Education into Courses, Comparative Research of Cultural Innovation, vol. 11, pp. 84-85, 2018.

[3] He Wei, Research on Integration of "Ideological and Political Education of Course" into the Teaching Path of College English Course, Journal of Zhongzhou University, vol. 36, pp. 96-100, 2019

[4] Li Xiaona, Problems and Countermeasures of Integrating Ideological and political education into College English Teaching, Read and Write Periodical, vol.16, pp.6, 16, 2019. 
[5] Design and Practice of Integrating Ideological and political Education into College English Courses,

Education Modernization, vol. 19, pp.208-209, 2019.

[6] Li Jie, Discussion on the Integration of Students' Ideological and political Education and College English Classroom Teaching, vol. 15, pp.143-144, 2017.

[7] Wang Yanli, The Reform and Implementation of College English Based on the Theory of Integrating Ideological and Political Education into Courses, The

Theory and Practice of Innovation and

Entrepreneurship, vol. 22, pp. 39-40, 2019. 